\title{
LEVEL II SCOUR ANALYSIS FOR BRIDGE 54 (RANDTH00BR0054) on BROOK STREET, crossing THAYER BROOK, RANDOLPH, VERMONT
}

U.S. Geological Survey Open-File Report 96-308

Prepared in cooperation with

VERMONT AGENCY OF TRANSPORTATION and

FEDERAL HIGHWAY ADMINISTRATION 


\section{LEVEL II SCOUR ANALYSIS FOR BRIDGE 54 (RANDTH00BR0054) on BROOK STREET, crossing THAYER BROOK, RANDOLPH, VERMONT \\ By SCOTT A. OLSON}

U.S. Geological Survey Open-File Report 96-308

Prepared in cooperation with

VERMONT AGENCY OF TRANSPORTATION and

FEDERAL HIGHWAY ADMINISTRATION 


\title{
U.S. DEPARTMENT OF THE INTERIOR BRUCE BABBITT, Secretary
}

\author{
U.S. GEOLOGICAL SURVEY \\ Gordon P. Eaton, Director
}

For additional information write to:

District Chief

U.S. Geological Survey 361 Commerce Way

Pembroke, NH 03275
Copies of this report may be purchased from:

U.S. Geological Survey Earth Science Information Center Open-File Reports Section Box 25286, MS 517 Federal Center

Denver, CO 80225 


\section{CONTENTS}

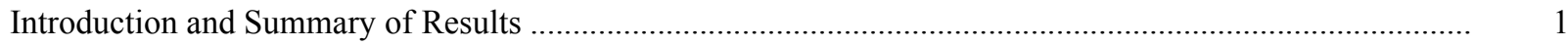

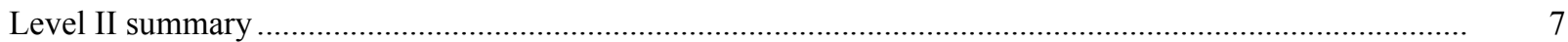

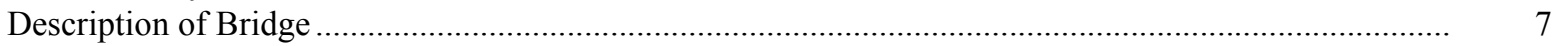

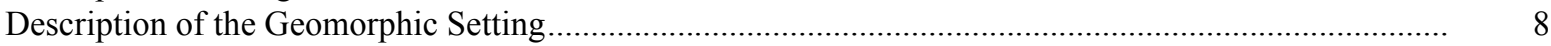

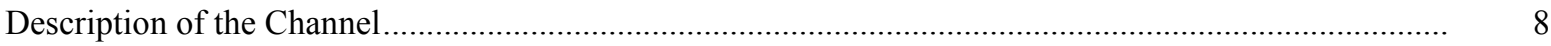

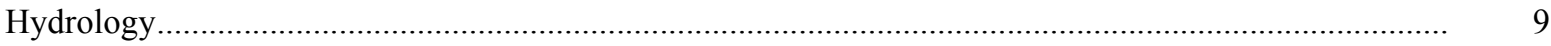

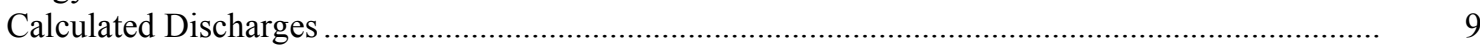

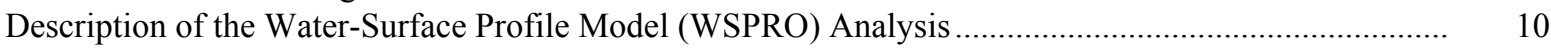

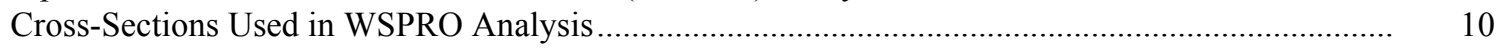

Data and Assumptions Used in WSPRO Model ...................................................................... 11

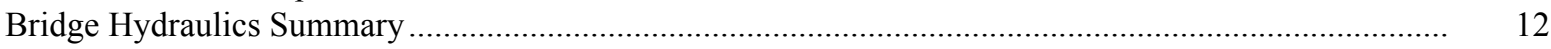

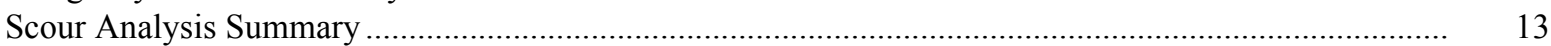

Special Conditions or Assumptions Made in Scour Analysis ...................................................... 13

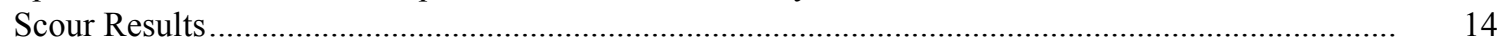

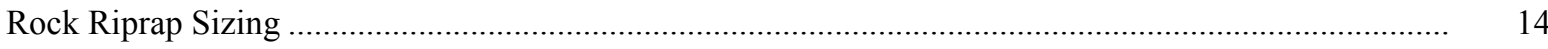

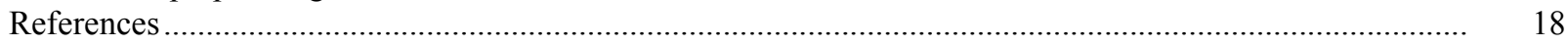

Appendixes:

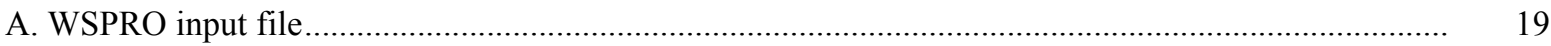

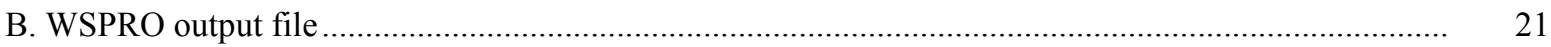

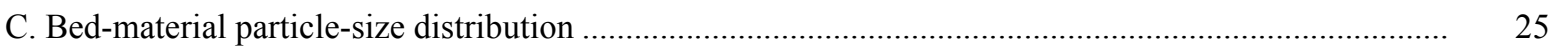

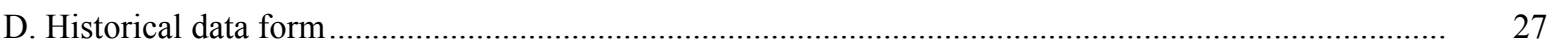

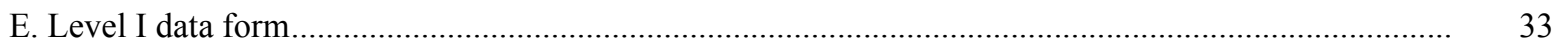

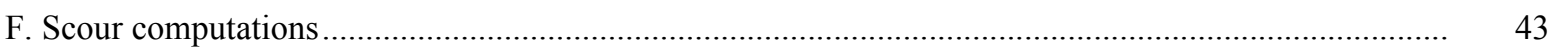

\section{FIGURES}

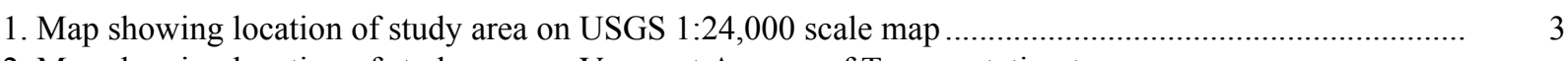

2. Map showing location of study area on Vermont Agency of Transportation town

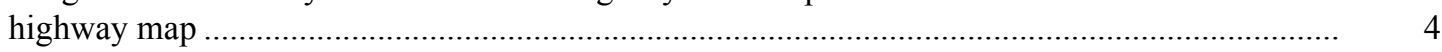

3. Structure RANDTH00BR0054 viewed from upstream (August 3, 1994) .............................................. 5

4. Downstream channel viewed from structure RANDTH00BR0054 (August 3, 1994)............................. 5

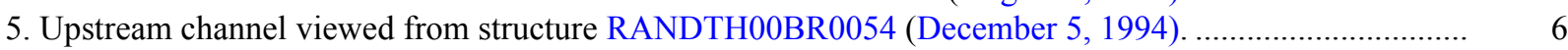

6. Structure RANDTH00BR0054 viewed from downstream (August 3, 1994) ........................................ 6

7. Water-surface profiles for the 100- and 500-year discharges at structure

RANDTH00BR0054 on Brook Street, crossing Thayer Brook,

Randolph, Vermont.

8. Scour elevations for the 100- and 500-year discharges at structure

RANDTH00BR0054 on Brook Street, crossing Thayer Brook,

Randolph, Vermont.

3

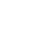

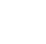

(1)

(

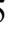

\section{TABLES}

1. Remaining footing/pile depth at abutments for the 100-year discharge at structure

RANDTH00BR0054 on Brook Street, crossing Thayer Brook,

Randolph, Vermont....

2. Remaining footing/pile depth at abutments for the 500-year discharge at structure

RANDTH00BR0054 on Brook Street, crossing Thayer Brook,

Randolph, Vermont. 


\begin{tabular}{|c|c|c|}
\hline Multiply & By & To obtain \\
\hline \multicolumn{3}{|c|}{ Length } \\
\hline inch (in.) & 25.4 & millimeter (mm) \\
\hline foot $(\mathrm{ft})$ & 0.3048 & meter $(\mathrm{m})$ \\
\hline mile (mi) & 1.609 & kilometer (km) \\
\hline \multicolumn{3}{|c|}{ Slope } \\
\hline foot per mile ( $\mathrm{ft} / \mathrm{mi})$ & 0.1894 & meter per kilometer $(\mathrm{m} / \mathrm{km})$ \\
\hline \multicolumn{3}{|c|}{ Area } \\
\hline square mile $\left(\mathrm{mi}^{2}\right)$ & 2.590 & square kilometer $\left(\mathrm{km}^{2}\right)$ \\
\hline \multicolumn{3}{|c|}{ Volume } \\
\hline cubic foot $\left(\mathrm{ft}^{3}\right)$ & $\begin{array}{l}0.02832 \\
\text { Velocity and Flow }\end{array}$ & cubic meter $\left(\mathrm{m}^{3}\right)$ \\
\hline foot per second (ft/s) & 0.3048 & meter per second $(\mathrm{m} / \mathrm{s})$ \\
\hline cubic foot per second $\left(\mathrm{ft}^{3} / \mathrm{s}\right)$ & 0.02832 & cubic meter per second $\left(\mathrm{m}^{3} / \mathrm{s}\right)$ \\
\hline $\begin{array}{l}\text { cubic foot per second per } \\
\text { square mile } \\
{\left[\left(\mathrm{ft}^{3} / \mathrm{s}\right) / \mathrm{mi}^{2}\right]}\end{array}$ & 0.01093 & $\begin{array}{l}\text { cubic meter per } \\
\text { second per square } \\
\text { kilometer }\left[\left(\mathrm{m}^{3} / \mathrm{s}\right) / \mathrm{km}^{2}\right]\end{array}$ \\
\hline
\end{tabular}

OTHER ABBREVIATIONS

$\begin{array}{lrlr}\mathrm{BF} & \text { bank full } & \text { LWW } & \text { left wingwall } \\ \mathrm{cfs} & \text { cubic feet per second } & \text { MC } & \text { main channel } \\ \mathrm{D}_{50} & \text { median diameter of bed material } & \text { RAB } & \text { right abutment } \\ \mathrm{DS} & \text { downstream } & \text { RABUT } & \text { face of right abutment } \\ \mathrm{elev} & \text { elevation } & \text { RB } & \text { right bank } \\ \mathrm{f} / \mathrm{p} & \text { flood plain } & \text { ROB } & \text { right overbank } \\ \mathrm{ft} & \text { square feet } & \text { RWW } & \text { right wingwall } \\ \mathrm{ft} / \mathrm{ft} & \text { feet per foot } & \text { TH } & \text { town highway } \\ \mathrm{JCT} & \text { junction } & \text { UB } & \text { under bridge } \\ \mathrm{LAB} & \text { left abutment } & \text { US } & \text { upstream } \\ \mathrm{LABUT} & \text { face of left abutment } & \text { USGS } & \text { United States Geological Survey } \\ \text { LB } & \text { left bank } & \text { VTAOT Vermont Agency of Transportation } \\ \text { LOB } & \text { left overbank } & \text { WSPRO } & \text { water-surface profile model }\end{array}$

In this report, the words "right" and "left" refer to directions that would be reported by an observer facing downstream. Sea level: In this report, "sea level" refers to the National Geodetic Vertical Datum of 1929-- a geodetic datum derived from a general adjustment of the first-order level nets of the United States and Canada, formerly called Sea Level Datum of 1929.

In the appendices, the above abbreviations may be combined. For example, USLB would represent upstream left bank. 


\title{
LEVEL II SCOUR ANALYSIS FOR BRIDGE 54 (RANDTH00BR0054) ON BROOK STREET, CROSSING THAYER BROOK, RANDOLPH, VERMONT
}

\author{
By Scott A. Olson
}

\section{INTRODUCTION AND SUMMARY OF RESULTS}

This report provides the results of a detailed Level II analysis of scour potential at structure RANDTH00BR0054 on Brook Street crossing Thayer Brook, Randolph, Vermont (figures $1-8)$. A Level II study is a basic engineering analysis of the site, including a quantitative analysis of stream stability and scour (U.S. Department of Transportation, 1993). A Level I study is included in Appendix E of this report. A Level I study provides a qualitative geomorphic characterization of the study site. Information on the bridge available from VTAOT files was compiled prior to conducting Level I and Level II analyses and can be found in Appendix D.

The site is in the Green Mountain physiographic division of central Vermont in the town of Randolph. The 5.39- $\mathrm{mi}^{2}$ drainage area is in a predominantly rural basin. In the vicinity of the study site, the immediate banks are forested.

In the study area, Thayer Brook has an incised, sinuous channel with a slope of approximately $0.03 \mathrm{ft} / \mathrm{ft}$, an average channel top width of $60 \mathrm{ft}$ and an average channel depth of $3 \mathrm{ft}$. The predominant channel bed materials are gravel and cobble $\left(\mathrm{D}_{50}\right.$ is $42.4 \mathrm{~mm}$ or $0.139 \mathrm{ft}$ ). The geomorphic assessment at the time of the Level I and Level II site visits on August 3, 1994 and December 5, 1994, indicated that the reach was vertically and laterally unstable. This assessment was due to the extreme channel misalignment with the bridge opening and the presence of a drop structure downstream of the bridge protecting against channel degradation.

The Brook Street crossing of Thayer Brook is a 34-ft-long, two-lane bridge consisting of one 31-foot concrete span (Vermont Agency of Transportation, written communication, August 2, 1994). The bridge is supported by vertical, concrete abutments with wingwalls. Streamflow attacks the upstream right wingwall and has undermined the upstream end of the right abutment. Type-2 stone fill (less than 36 inches diameter) exists only on the upstream and downstream sides of the left road embankment. No other protection was noted. The bank full channel skew at the bridge face is approximately 20 degrees; the opening-skew-to-roadway is also 20 degrees. Additional details describing conditions at the site are included in the Level II Summary and Appendices D and $\mathrm{E}$. 
Scour depths and rock rip-rap sizes were computed using the general guidelines described in Hydraulic Engineering Circular 18 (Richardson and others, 1993). Total scour at a highway crossing is comprised of three components: 1) long-term streambed degradation; 2) contraction scour (due to accelerated flow caused by a reduction in flow area at a bridge) and; 3) local scour (caused by accelerated flow around piers and abutments). Total scour is the sum of the three components. Equations are available to compute depths for contraction and local scour and a summary of the results of these computations follows.

Contraction scour for all modelled flows ranged from 1.3 to $2.7 \mathrm{ft}$. The worst-case contraction scour occurred at the 500-year discharge. Abutment scour ranged from 5.3 to $15.1 \mathrm{ft}$. and the worst-case abutment scour also occurred at the 500-year discharge. Additional information on scour depths and depths to armoring are included in the section titled "Scour Results". Scoured-streambed elevations, based on the calculated scour depths, are presented in tables 1 and 2. A cross-section of the scour computed at the bridge is presented in figure 8 . Scour depths were calculated assuming an infinite depth of erosive material and a homogeneous particle-size distribution.

It is generally accepted that the Froehlich equation (abutment scour) gives "excessively conservative estimates of scour depths" (Richardson and others, 1993, p. 48). Many factors, including historical performance during flood events, the geomorphic assessment, scour protection measures, and the results of the hydraulic analyses, must be considered to properly assess the validity of abutment scour results. Therefore, scour depths adopted by VTAOT may differ from the computed values documented herein, based on the consideration of additional contributing factors and experienced engineering judgement. 


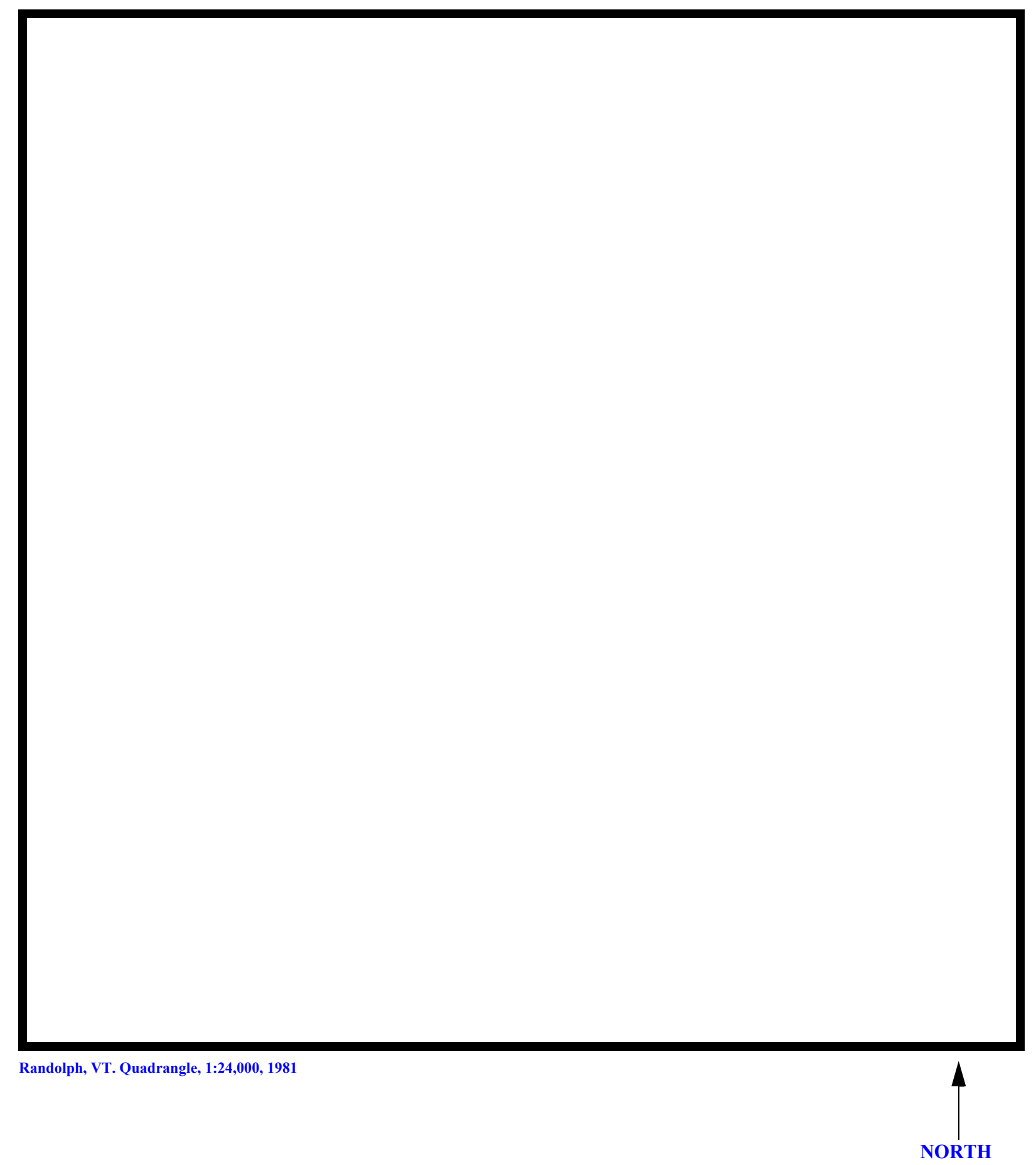

Figure 1. Location of study area on USGS 1:24,000 scale map. 
Figure 2. Location of study area on Vermont Agency of Transportation town highway map. 

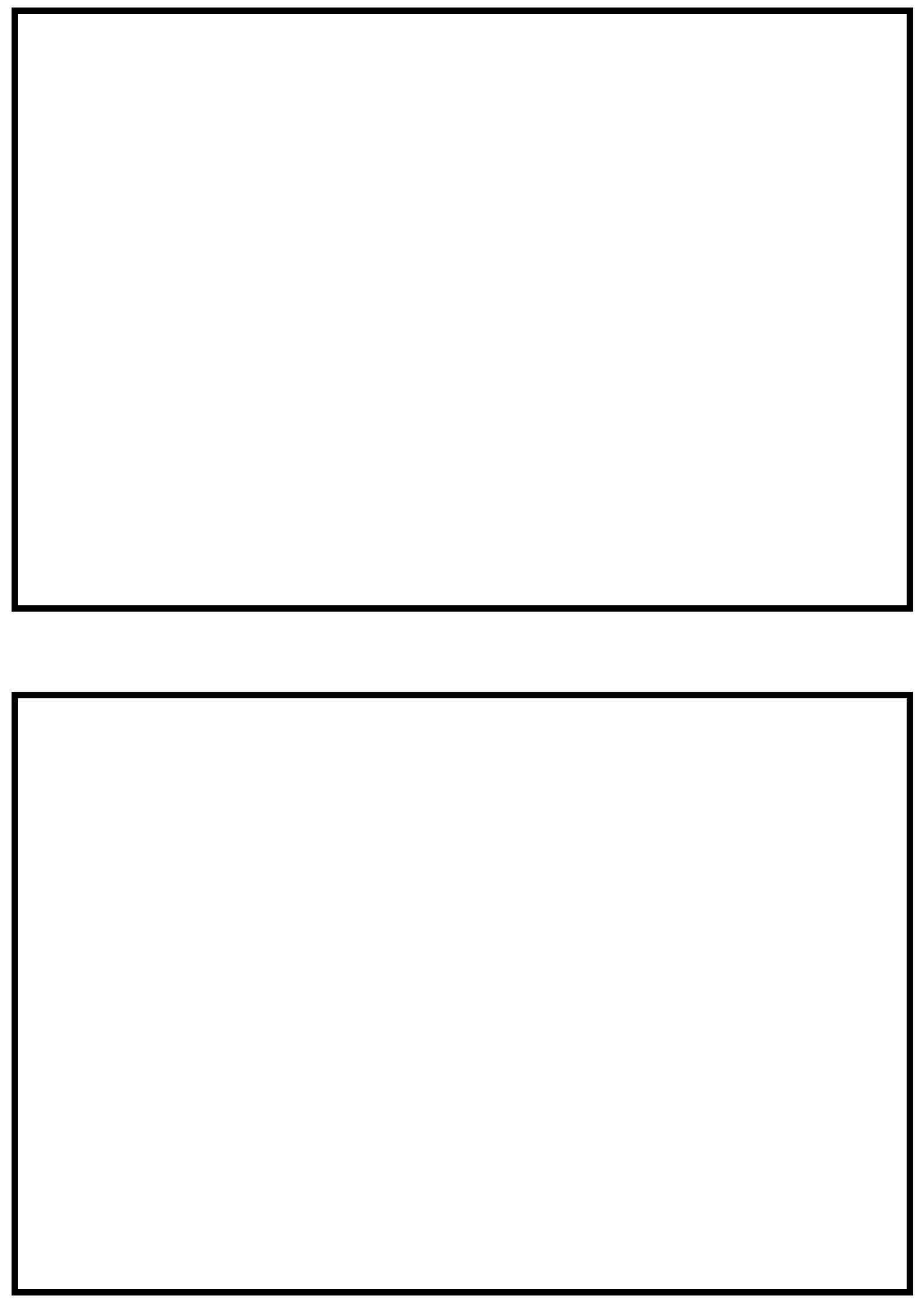

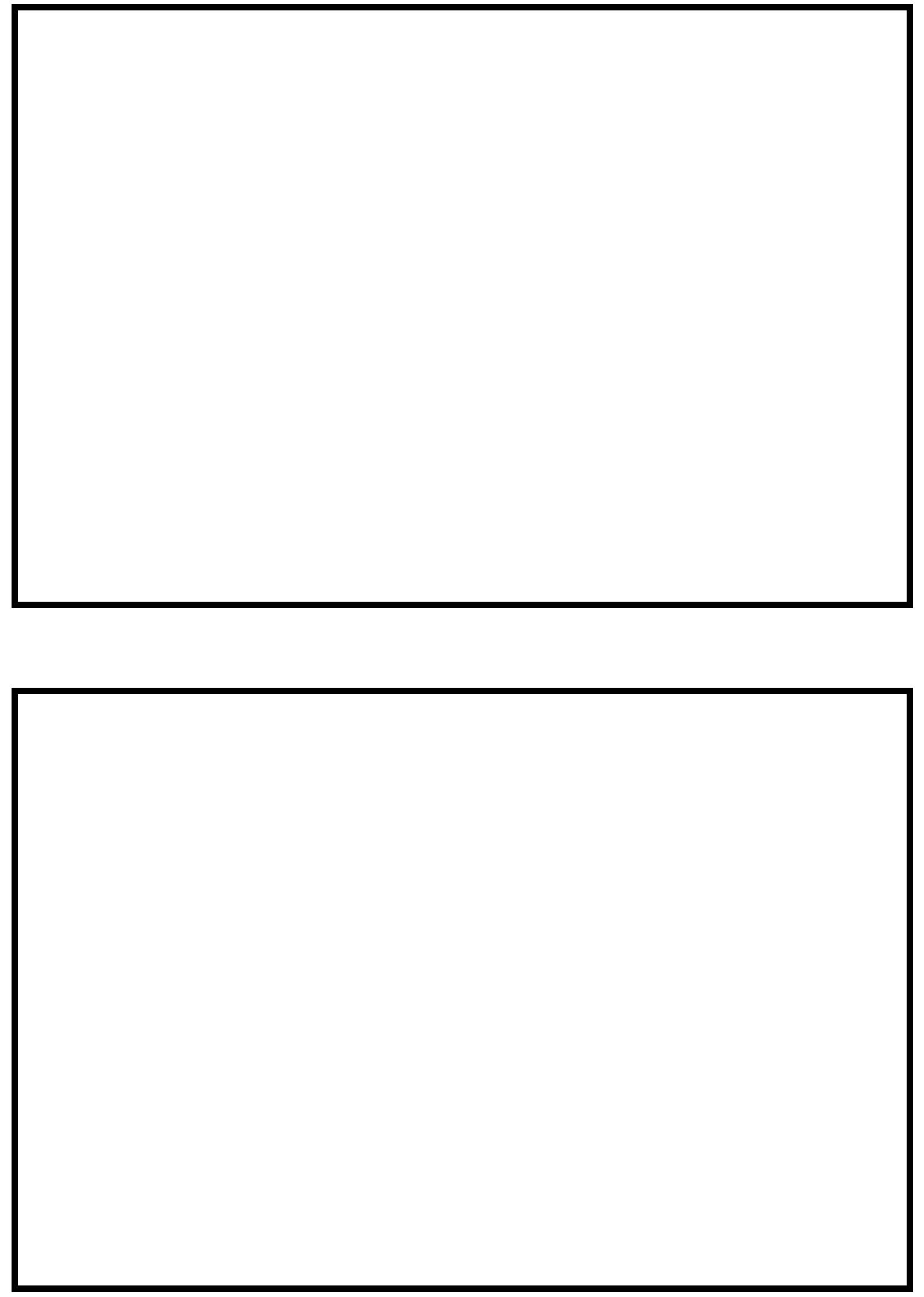


\section{LEVEL II SUMMARY}

\begin{tabular}{llllll} 
& Structure Number & RANDTH00BR0054 & & \multicolumn{2}{c}{ Thayer Brook } \\
Stream & & & \\
County & Orange & Road & TH00BR & District & 04 \\
& & &
\end{tabular}

\section{Description of Bridge}

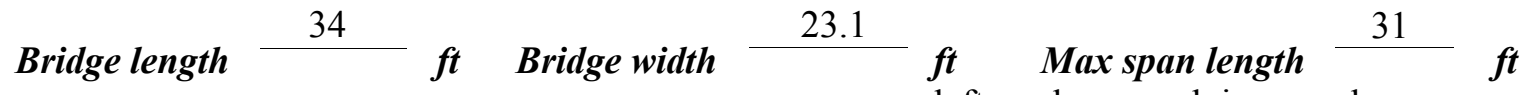
Alignment of bridge to road (on curve or straight) vertical and concrete Abutment type

Stone fill on abutment? no

\section{Embankment type} left road approach is curved

\section{Y} 'survey?
20

$$
\text { Angle }
$$

There is a moderate bend upstream. The channel approạch to the bridge has shifted to the right and flows attack the right wingwall.

Debris accumulation on bridge at time of Level I or Level II site visit:

\section{Drto af incnortion $8 / 3 / 94$ and $12 / 5 / 940$}

Level I

\section{4}

\section{Percent of nhammol blocked inortzontaty}

Percent of $08 / 03 /$ iel blocked verticatty

\section{Level II}

Moderate due to cut banks and debris accumulation upstream.

August 3, 1994 and December 5, 1994. The stream impacts the upstream right wingwall due Potential for debris

to poor alignment between the bridge and the channel. There is a drop structure 29 feet Doscriho anv foaturos noar ar at tho hridoo that mav, affort flow, (includo ahsorvation datol downstream of the bridge. 


\section{Description of the Geomorphic Setting}

General topography The bridge crosses a high gradient upland stream with narrow flood plains in a moderate relief valley.

Geomorphic conditions at bridge site: downstream (DS), upstream (US)

Date of inspection $\quad 08 / 03 / 94$ and 12/05/94

DS left: $\quad$ Steep, 8 foot high channel bank with moderately sloping overbank

DS right: $\quad$ Steep channel bank to narrow flood plain.

US left: $\quad$ Steep valley wall.

US right: $\quad$ Steep channel bank to narrow flood plain.

\section{Description of the Channel}

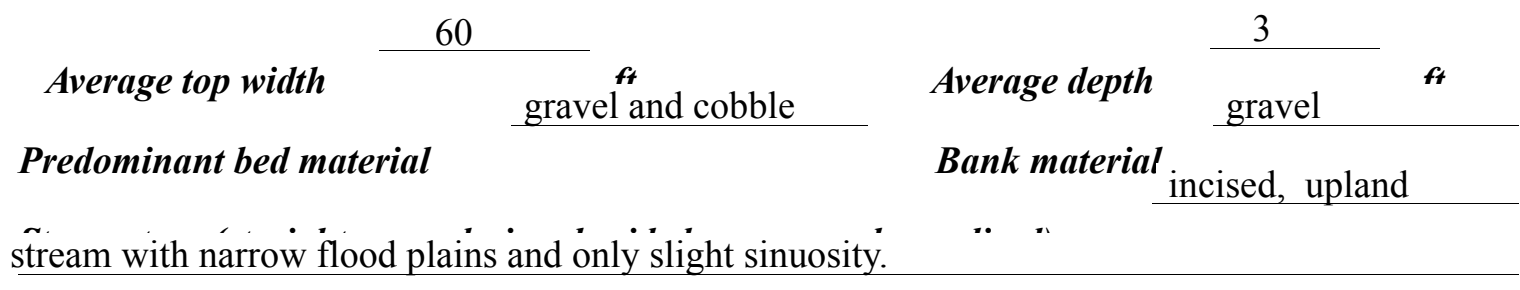

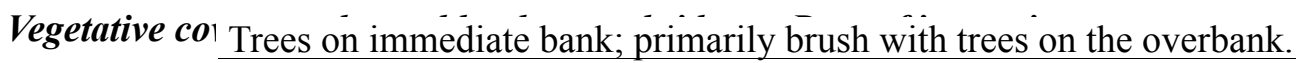

DS left: $\quad$ Forested.

DS right: $\quad$ Forested.

US left: $\quad$ Trees on immediate bank; primarily brush and grass on the overbank.

US right:

$\mathrm{N}$

Do banks appear stable? August 3, 1994, and December 5 , 1994. The channel approach to the bridge has laterally moved to the right and is now impacting the right abutment. There is also
date of observatton. vertical instability. A drop structure has been constructed downstream of the bridge to prevent further degradation.

August 3, 1994 and

December 5, 1994. None.

Describe any obstructions in channel and date of observation. 


\title{
Hydrology
}

Drainage area $\quad 5.39 \boldsymbol{m i}^{2}$

Percentage of drainage area in physiographic provinces: (approximate)

Physiographic province

Green Mountain Prov.
Percent of drainage area

100

\begin{abstract}
Is drainage area considered rural or urban?
Rural None.

urbanization:-

Describe any significant
\end{abstract}

Is there a USGS gage on the stream of interest?

No

\section{USGS gage description}

USGS gage number

Gage drainage area

$m i^{2}$

No

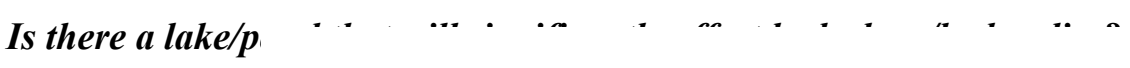

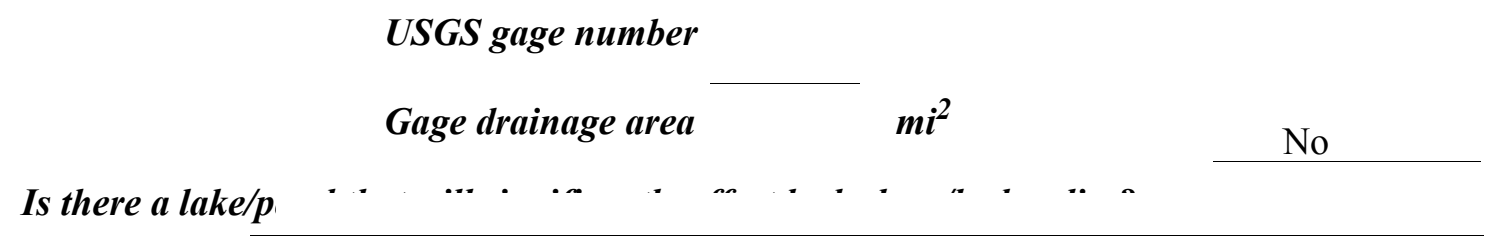

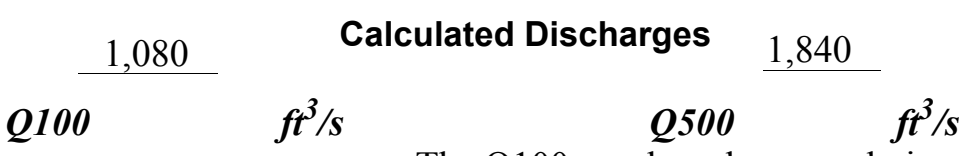

The Q100 was based upon a drainage area

relationship [(5.4/3.5) to the 0.7 power] with a site on Thayer Brook with flood frequency estimates available from VTAOT (Landry, D., oral communication, March 1995). This site had a drainage area of 3.5 square miles. Q500 was estimated by multiplying the Q100 by 1.7

(Richardson and others, 1983). 


\section{Description of the Water-Surface Profile Model (WSPRO) Analysis}

Datum for WSPRO analysis (USGS survey, sea level, VTAOT plans)

USGS survey

Datum tie between USGS survey and VTAOT plans Not applicable.

Description of reference marks used to determine USGS datum. $\quad$ RM1 is a chiseled

square on the top of the upstream end of the left abutment (elev. $518.25 \mathrm{ft}$, arbitrary datum).

Cross-Sections Used in WSPRO Analysis

\begin{tabular}{|c|c|c|c|}
\hline${ }^{1}$ Cross-section & $\begin{array}{c}\text { Section } \\
\text { Reference } \\
\text { Distance } \\
\text { (SRD) in feet }\end{array}$ & $\begin{array}{l}{ }^{2} \text { Cross-section } \\
\text { development }\end{array}$ & Comments \\
\hline Drop & 35 & 1 & $\begin{array}{l}\text { EXIT section (on the drop } \\
\text { structure) }\end{array}$ \\
\hline FV & 60 & 2 & $\begin{array}{l}\text { Downstream full valley } \\
\text { section (templated from } \\
\text { Drop) }\end{array}$ \\
\hline $\mathrm{BR}$ & 73 & 2 & $\begin{array}{l}\text { Bridge section (moved to } \\
\text { SRD of bridge centerline). }\end{array}$ \\
\hline UFACE & 86 & 2 & $\begin{array}{l}\text { Upstream full valley sec- } \\
\text { tion (templated from } \\
\text { APPR) }\end{array}$ \\
\hline APPR & 140 & 1 & $\begin{array}{l}\text { Approach section (identi- } \\
\text { cal to APTEM) }\end{array}$ \\
\hline APTEM & 140 & 1 & $\begin{array}{l}\text { Surveyed approach sec- } \\
\text { tion (used as a template } \\
\text { for the unconstricted } \\
\text { upstream bridge face sec- } \\
\text { tion--UFACE). }\end{array}$ \\
\hline
\end{tabular}

${ }^{1}$ For location of cross-sections see plan-view sketch included with Level I field form, Appendix E. For more detail on how cross-sections were developed see WSPRO input file. 


\section{Data and Assumptions Used in WSPRO Model}

Hydraulic analyses of the reach were done by use of the Federal Highway Administration's WSPRO step-backwater computer program (Shearman and others, 1986, and Shearman, 1990). The analysis reported herein reflects conditions existing at the site at the time of the study. Furthermore, in the development of the model it was necessary to assume no accumulation of debris or ice at the site. Results of the hydraulic model are presented in the Bridge Hydraulic Summary, Appendix B, and figure 7.

Channel roughness factors (Manning's " $n$ ") used in the hydraulic model were estimated using field inspections at each cross section following the general guidelines described by Arcement, Jr. and Schneider (1989). Final adjustments to the values were made during the modelling of the reach. Channel " $n$ " values for the reach ranged from 0.030 to 0.040 , and overbank " $\mathrm{n}$ " values ranged from 0.050 to 0.085 .

The starting water surface elevation for the bridge model was determined by a submerged sharpcrested weir computation since a drop structure existed downstream of the bridge. First, a tailwater elevation was necessary for the weir computation. A section surveyed 30 feet downstream of the drop structure was propagated to the downstream face of the drop structure and normal depth was assumed for this section. This depth was computed by use of the slope-conveyance method outlined in the User's manual for WSPRO (Shearman, 1990). The slope used was $0.03 \mathrm{ft} / \mathrm{ft}$ which is the slope of the thalweg downstream of the drop structure. The calculated tailwater elevations at the drop structure for the 100-year and 500-year events were 499.0 and $499.8 \mathrm{ft}$. The crest of the weir is $498.7 \mathrm{ft}$.

Submerged sharp-crested weir computations (Brater and King, 1982, pp 5-4 to 5-17) were then done to determine the headwater elevations at the drop structure. The headwater elevations for the 100 -year and 500 -year events were 502.0 and $503.5 \mathrm{ft}$, respectively. These elevations were then used as the starting watersurface elevation for the bridge model.

WSPRO's bridge routines were not used in this model. A simple step-backwater model was utilized with the bridge section modelled at the centerline of the bridge and unconstricted sections at each face of the bridge templated from the respective upstream or downstream section. For example, the surveyed approach section was adjusted for the approach channel slope and put at the upstream face of the bridge.

For the modelled discharges, WSPRO assumes critical depth at the bridge section. Supercritical models were developed. Analyzing both the supercritical and subcritical profiles for each discharge, it can be determined that the water surface profile does pass through critical depth within the bridge opening. Thus, the assumptions of critical depth at the bridge are satifactory solutions. 


\section{Bridge Hydraulics Summary}

$\begin{array}{lrl}\text { Average bridge embankment elevation } & 518.0 \\ \text { Average low steel elevation } & 515.7 & f t\end{array}$

100-year discharge $\quad 1,080 \quad \mathrm{ft}^{3} / \mathrm{s}$

Water-surface elevation in bridge opening $\quad 502.4 \quad f t$

Road overtopping? ___ N Discharge over road __ _- , s

Area of flow in bridge opening $\quad 99.0 \quad \mathrm{ft}^{2}$

Average velocity in bridge opening $10.9 \mathrm{ft} / \mathrm{s}$

Maximum WSPRO tube velocity at bridge $\quad 12.8 \mathrm{ft} / \mathrm{s}$

Water-surface elevation at Approach section with bridge

Water-surface elevation at Approach section without bridge

504.3

Amount of backwater caused by bridge

$$
\mathrm{N} / \mathrm{A}_{-} \boldsymbol{t}
$$

500-year discharge $\quad 1,840 \quad \mathrm{ft}^{3} / \mathrm{s}$

Water-surface elevation in bridge opening $\quad 503.9 f t$

Road overtopping? ___ N Discharge over road $--\ldots . / s$

Area of flow in bridge opening $\quad 141.2 \quad \mathrm{ft}^{2}$

Average velocity in bridge opening $\quad 13.0 \mathrm{ft} / \mathrm{s}$

Maximum WSPRO tube velocity at bridge 15.8 _s

Water-surface elevation at Approach section with bridge

Water-surface elevation at Approach section without bridge

506.5

Amount of backwater caused by bridge N/A

Incipient overtopping discharge ___ -- $\mathrm{ft}^{3} / \mathrm{s}$

Water-surface elevation in bridge opening $\quad--\quad$ it

Area of flow in bridge opening

$-f_{--}$

Average velocity in bridge opening

Maximum WSPRO tube velocity at bridge

$-f^{-} / \mathrm{s}$

Water-surface elevation at Approach section with bridge

Water-surface elevation at Approach section without bridge

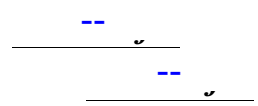
Amount of backwater caused by bridge

$-{ }_{-}^{-} \mathrm{t}$ 


\section{Scour Analysis Summary}

\section{Special Conditions or Assumptions Made in Scour Analysis}

Scour depths were computed using the general guidelines described in Hydraulic Engineering Circular 18 (Richardson and others, 1993). Scour depths were calculated assuming an infinite depth of erosive material and a homogeneous particle-size distribution. The results of the scour analysis are presented in tables 1 and 2 and a graph of the scour depths is presented in figure 8.

Contraction scour was computed by use of the clear-water contraction scour equation (Richardson and others, 1993, p. 35, equation 18). For contraction scour computations, the average depth in the contracted section (AREA/TOPWIDTH) is subtracted from the depth of flow computed by the scour equation (Y2) to determine the actual amount of scour.

Abutment scour was computed by use of the Froehlich equation (Richardson and others, 1993, p. 49, equation 24). Variables for the Froehlich equation include the Froude number of the flow approaching the embankments, the length of the embankment blocking flow, and the depth of flow approaching the embankment less any roadway overtopping. 


\section{Scour Results}

$$
\text { 100-yr discharge 500-yr discharge }
$$

Contraction scour:

Main channel

Live-bed scour

Clear-water scour

Depth to armoring

Left overbank

Right overbank

Local scour:

Abutment scour

Left abutment

Right abutment

Pier scour

Pier 1

Pier 2

Pier 3
(Scour depths in feet)

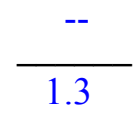

$$
26.2^{-}
$$
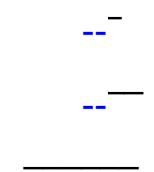

5.3

13.9-
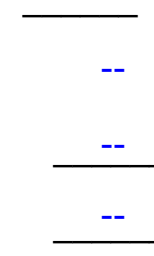

8.5

$15.1-$
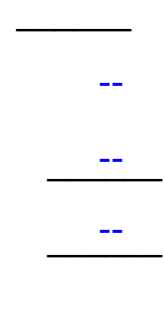

Incipient
chtopping
charge 


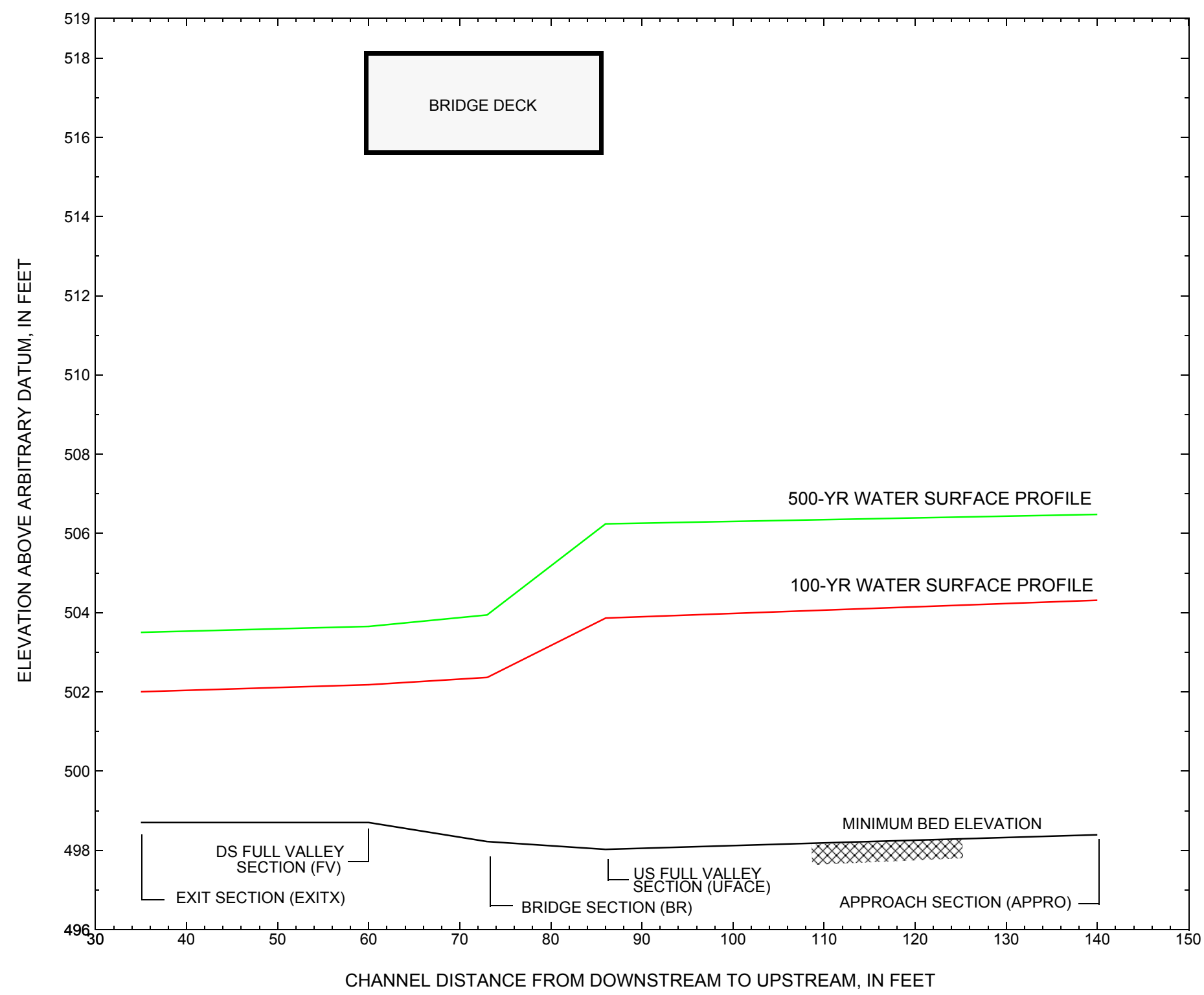

Figure 7. Water-surface profiles for the 100- and 500-yr discharges at structure RANDTH00BR0054 on Brook Street, crossing Thayer Brook, Randolph, Vermont. 


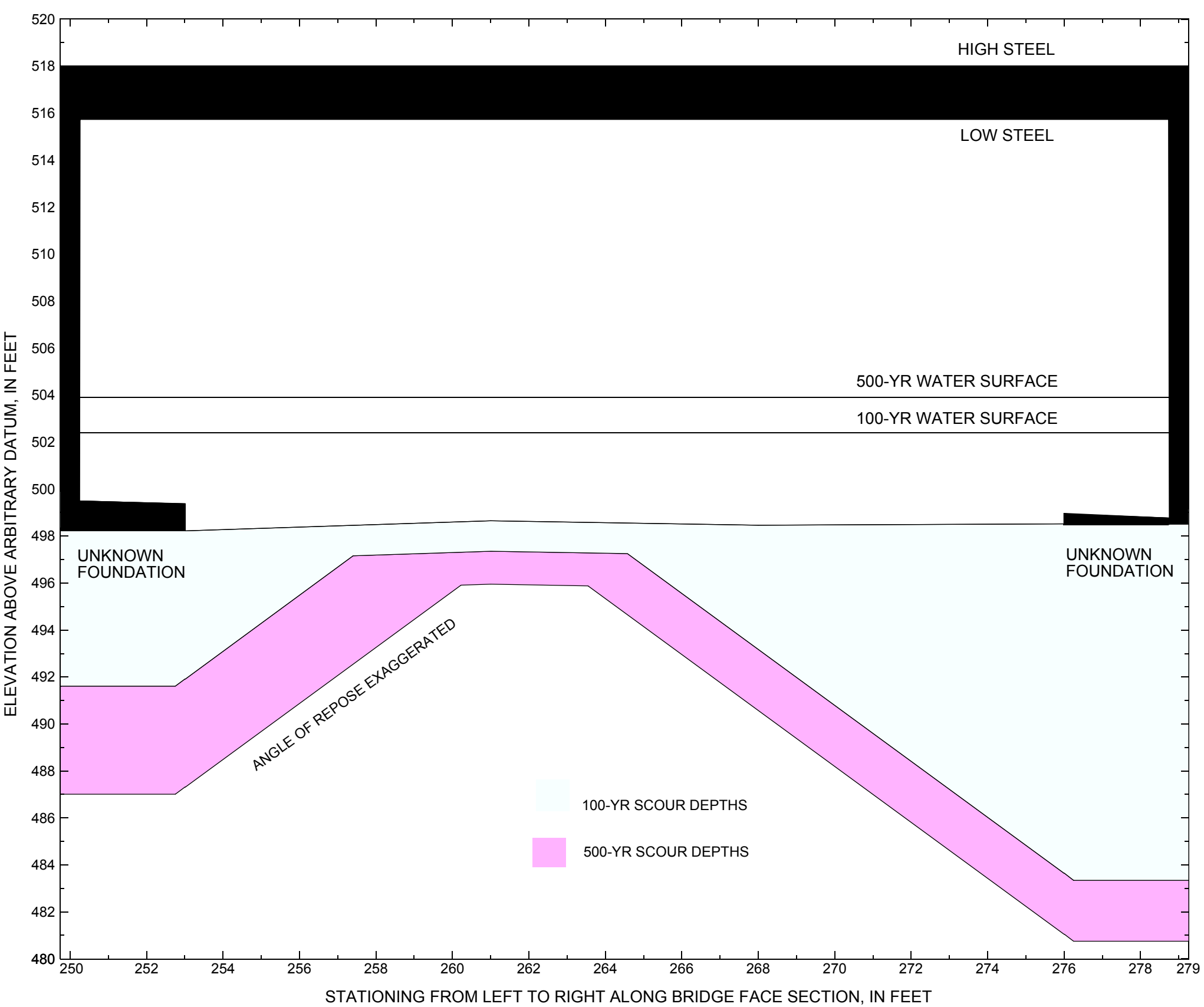

Figure 8. Scour elevations for the 100-yr and 500-yr discharges at structure RANDTH00BR0054 on Brook Street, crossing Thayer Brook, Randolph, Vermont. 
Table 1. Remaining footing/pile depth at abutments for the 100-year discharge at structure RANDTH00BR0054 on Brook Street, crossing Thayer Brook, Randolph, Vermont. [VTAOT, Vermont Agency of Transportation; --,no data]

\begin{tabular}{|c|c|c|c|c|c|c|c|c|c|c|c|}
\hline Description & Station $^{1}$ & $\begin{array}{l}\text { VTAOT } \\
\text { minimum } \\
\text { low-chord } \\
\text { elevation } \\
\text { (feet) }\end{array}$ & $\begin{array}{l}\text { Surveyed } \\
\text { minimum } \\
\text { low-chord } \\
\text { elevation } \\
\text { (feet) }\end{array}$ & $\begin{array}{c}\text { Bottom of } \\
\text { footing } \\
\text { elevation } \\
\text { (feet) }\end{array}$ & $\begin{array}{l}\text { Channel } \\
\text { elevation at } \\
\text { abutment/ } \\
\text { pier }^{2} \\
\text { (feet) }\end{array}$ & $\begin{array}{l}\text { Contraction } \\
\text { scour depth } \\
\text { (feet) }\end{array}$ & $\begin{array}{l}\text { Abutment } \\
\text { scour } \\
\text { depth } \\
\text { (feet) }\end{array}$ & $\begin{array}{l}\text { Pier } \\
\text { scour } \\
\text { depth } \\
\text { (feet) }\end{array}$ & $\begin{array}{l}\text { Depth of } \\
\text { total scour } \\
\text { (feet) }\end{array}$ & $\begin{array}{c}\text { Elevation of } \\
\text { scour }^{2} \\
\text { (feet) }\end{array}$ & $\begin{array}{c}\text { Remaining } \\
\text { footing/pile } \\
\text { depth } \\
\text { (feet) }\end{array}$ \\
\hline \multicolumn{12}{|c|}{100 -yr. discharge is 1,080 cubic-feet per second } \\
\hline Left abutment & 250 & -- & 515.7 & -- & 498.2 & 1.3 & 5.3 & -- & 6.6 & 491.6 & -- \\
\hline Right abutment & 279 & -- & 515.7 & -- & 498.5 & 1.3 & 13.9 & -- & 15.2 & 483.3 & -- \\
\hline
\end{tabular}

1. Measured along the face of the most constricting side of the bridge.

2. Arbitrary datum for this study.

Table 2. Remaining footing/pile depth at abutments for the 500-year discharge at structure RANDTH00BR0054 on Brook Street, crossing Thayer Brook, Randolph, Vermont. [VTAOT, Vermont Agency of Transportation; --, no data]

\begin{tabular}{|c|c|c|c|c|c|c|c|c|c|c|c|}
\hline Description & Station $^{1}$ & $\begin{array}{l}\text { VTAOT } \\
\text { minimum } \\
\text { low-chord } \\
\text { elevation } \\
\text { (feet) }\end{array}$ & $\begin{array}{l}\text { Surveyed } \\
\text { minimum } \\
\text { low-chord } \\
\text { elevation } \\
\text { (feet) }\end{array}$ & $\begin{array}{c}\text { Bottom of } \\
\text { footing } \\
\text { elevation } \\
\text { (feet) }\end{array}$ & $\begin{array}{c}\text { Channel } \\
\text { elevation at } \\
\text { abutment/ } \\
\text { pier }^{2} \\
\text { (feet) }\end{array}$ & $\begin{array}{l}\text { Contraction } \\
\text { scour depth } \\
\text { (feet) }\end{array}$ & $\begin{array}{l}\text { Abutment } \\
\text { scour } \\
\text { depth } \\
\text { (feet) }\end{array}$ & $\begin{array}{l}\text { Pier } \\
\text { scour } \\
\text { depth } \\
\text { (feet) }\end{array}$ & $\begin{array}{l}\text { Depth of } \\
\text { total scour } \\
\text { (feet) }\end{array}$ & $\begin{array}{c}\text { Elevation of } \\
\text { scour }^{2} \\
\text { (feet) }\end{array}$ & $\begin{array}{c}\text { Remaining } \\
\text { footing/pile } \\
\text { depth } \\
\text { (feet) }\end{array}$ \\
\hline \multicolumn{12}{|c|}{500 -yr. discharge is 1,840 cubic-feet per second } \\
\hline Left abutment & 250 & -- & 515.7 & -- & 498.2 & 2.7 & 8.5 & -- & 11.2 & 487.0 & -- \\
\hline Right abutment & 279 & -- & 515.7 & -- & 498.5 & 2.7 & 15.1 & -- & 17.8 & 480.7 & -- \\
\hline
\end{tabular}

${ }^{1 \cdot}$ Measured along the face of the most constricting side of the bridge.

2. Arbitrary datum for this study. 


\section{SELECTED REFERENCES}

Arcement, G.J., Jr., and Schneider, V.R., 1989, Guide for selecting Manning's roughness coefficients for natural channels and flood plains: U.S. Geological Survey Water-Supply Paper 2339, 38 p.

Barnes, H.H., Jr., 1967, Roughness characteristics of natural channels: U.S. Geological Survey Water-Supply Paper 1849, 213 p.

Brater, E.F., and King, H.W., 1982, Handbook of Hydraulics, McGraw-Hill Book Company.

Brown, S.A. and Clyde, E.S., 1989, Design of riprap revetment: Federal Highway Administration Hydraulic Engineering Circular No. 11, Publication FHWA-IP-89-016, 156 p.

Federal Emergency Management Agency, 1987, Flood Insurance Study, Town and Village of Randolph, Orange County, Vermont: Washington, D.C., January 16, 1987.

Froehlich, D.C., 1989, Local scour at bridge abutments in Ports, M.A., ed., Hydraulic Engineering--Proceedings of the 1989 National Conference on Hydraulic Engineering: New York, American Society of Civil Engineers, p. 13-18.

Hayes, D.C.,1993, Site selection and collection of bridge-scour data in Delaware, Maryland, and Virginia: U.S. Geological Survey WaterResources Investigation Report 93-4017, 23 p.

Interagency Advisory Committee on Water Data, 1982, Guidelines for determining flood flow frequency: U.S. Geological Survey, Bulletin 17B of the Hydrology Subcommittee, 190 p.

Johnson, C.G. and Tasker, G.D.,1974, Progress report on flood magnitude and frequency of Vermont streams: U.S. Geological Survey Open-File Report 74-130, 37 p.

Lagasse, P.F., Schall, J.D., Johnson, F., Richardson, E.V., Richardson, J.R., Chang, F., 1991, Stream Stability at Highway Structures: Federal Highway Administration Hydraulic Engineering Circular No. 20, Publication FHWA-IP-90-014, 195 p.

Laursen, E.M., 1960, Scour at bridge crossings: Journal of the Hydraulics Division, American Society of Civil Engineers, v. 86, no. HY2, p. 39-53.

Richardson, E.V., Harrison, L.J., Richardson, J.R., and Davis, S.R., 1993, Evaluating scour at bridges: Federal Highway Administration Hydraulic Engineering Circular No. 18, Publication FHWA-IP-90-017, 131 p.

Richardson, E.V., Simons, D.B., and Julien, P.Y., 1990, Highways in the river environment: Federal Highway Administration Publication FHWA-HI-90-016.

Ritter, D.F., 1984, Process Geomorphology: W.C. Brown Co., Debuque, Iowa, 603 p.

Shearman, J.O., 1990, User's manual for WSPRO--a computer model for water surface profile computations: Federal Highway Administration Publication FHWA-IP-89-027, 187 p.

Shearman, J.O., Kirby, W.H., Schneider, V.R., and Flippo, H.N., 1986, Bridge waterways analysis model; research report: Federal Highway Administration Publication FHWA-RD-86-108, 112 p.

U.S. Department of Transportation, 1993, Stream stability and scour at highway bridges, Participant Workbook: Federal Highway Administration Publication FHWA HI-91-011.

U.S. Geological Survey, 1981, Randolph, Vermont 7.5 Minute Series quadrangle map: U.S. Geological Survey Topographic Maps, Scale 1:24,000. 


\section{APPENDIX A: \\ WSPRO INPUT FILE}




\section{WSPRO INPUT FILE}

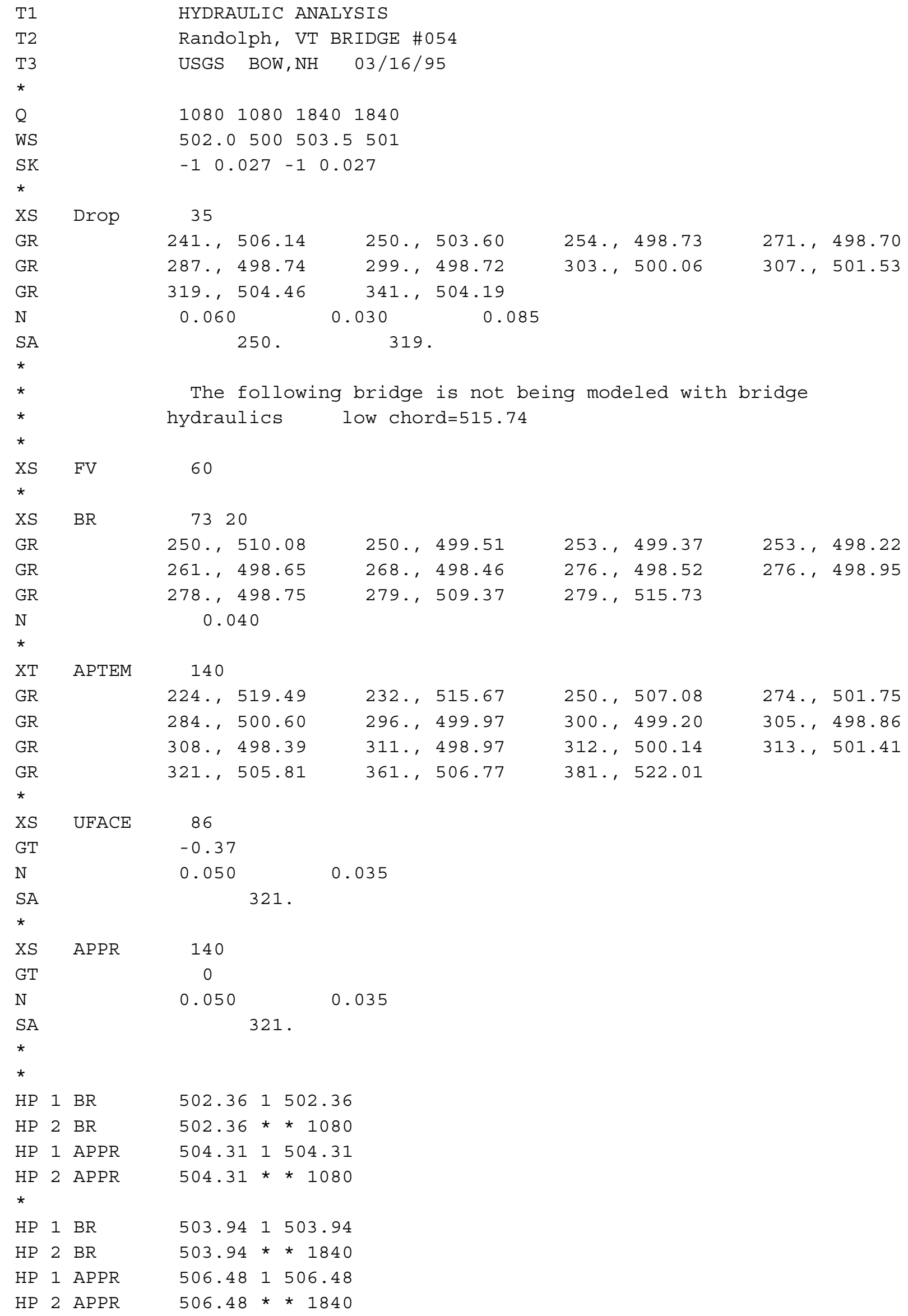

SK

*

XS Drop 35

GR

GR

GR

$\mathrm{N}$

SA

*

*

*

*

Xs

*

$\mathrm{XS}$

GR

GR

GR

$\mathrm{N}$

*

$\mathrm{XT}$

GR

GR

GR

GR

*

XS UFACE 86

GT $\quad-0.37$

$\mathrm{N}$

SA

*

XS APPR $\quad 140$

GT 0

$\mathrm{N}$

SA

*

*

HP 1 BR

HP 2 BR

HP 1 APPR

HP 2 APPR

*

$\mathrm{HP} 1 \mathrm{BR}$

HP 2 BR

HP 1 APPR

HP 2 APPR

HYDRAULIC ANALYSIS

Randolph, VT BRIDGE \#054

USGS BOW, NH 03/16/95

$\begin{array}{llll}1080 & 1080 & 1840 & 1840\end{array}$

$502.0 \quad 500 \quad 503.5 \quad 501$

$\begin{array}{llll}-1 & 0.027 & -1 & 0.027\end{array}$

$$
\begin{array}{ccc}
241 ., 506.14 & 250 ., & 503.60 \\
287 ., \quad 498.74 & 299 ., & 498.72 \\
319 ., 504.46 & 341 ., & 504.19 \\
0.060 & 0.030 & 0 . \\
250 . & 319 . &
\end{array}
$$

$254 ., 498.73$

$303 ., 500.06$

$271 ., 498.70$

$307 ., 501.53$

The following bridge is not being modeled with bridge hydraulics low chord=515.74

60$$
7320
$$$$
250 ., 510.08
$$

$261 ., 498.65$

$250 ., 499.51$

$268 ., 498.46$

$253 ., 499.37$

$276 ., 498.52$

$279 ., 509.37$

$279 ., 515.73$

0.040

140

$224 ., 519.49$

$232 ., 515.67$

$296 ., 499.97$

$311 ., 498.97$

$361 ., 506.77$

$250 ., 507.08$

$300 ., 499.20$

$312 ., 500.14$

$381 ., 522.01$

$253 ., 498.22$

$276 ., 498.95$

$274 ., 501.75$

$305 ., 498.86$

$313 ., 501.41$

0.050

0.035

321.

502.361502 .36

$502.36 * * 1080$

504.311504 .31

$504.31 * * 1080$

503.941503 .94

$503.94 * * 1840$

506.481506 .48

$506.48 * * 1840$ 


\section{APPENDIX B: \\ WSPRO OUTPUT FILE}


WSPRO OUTPUT FILE

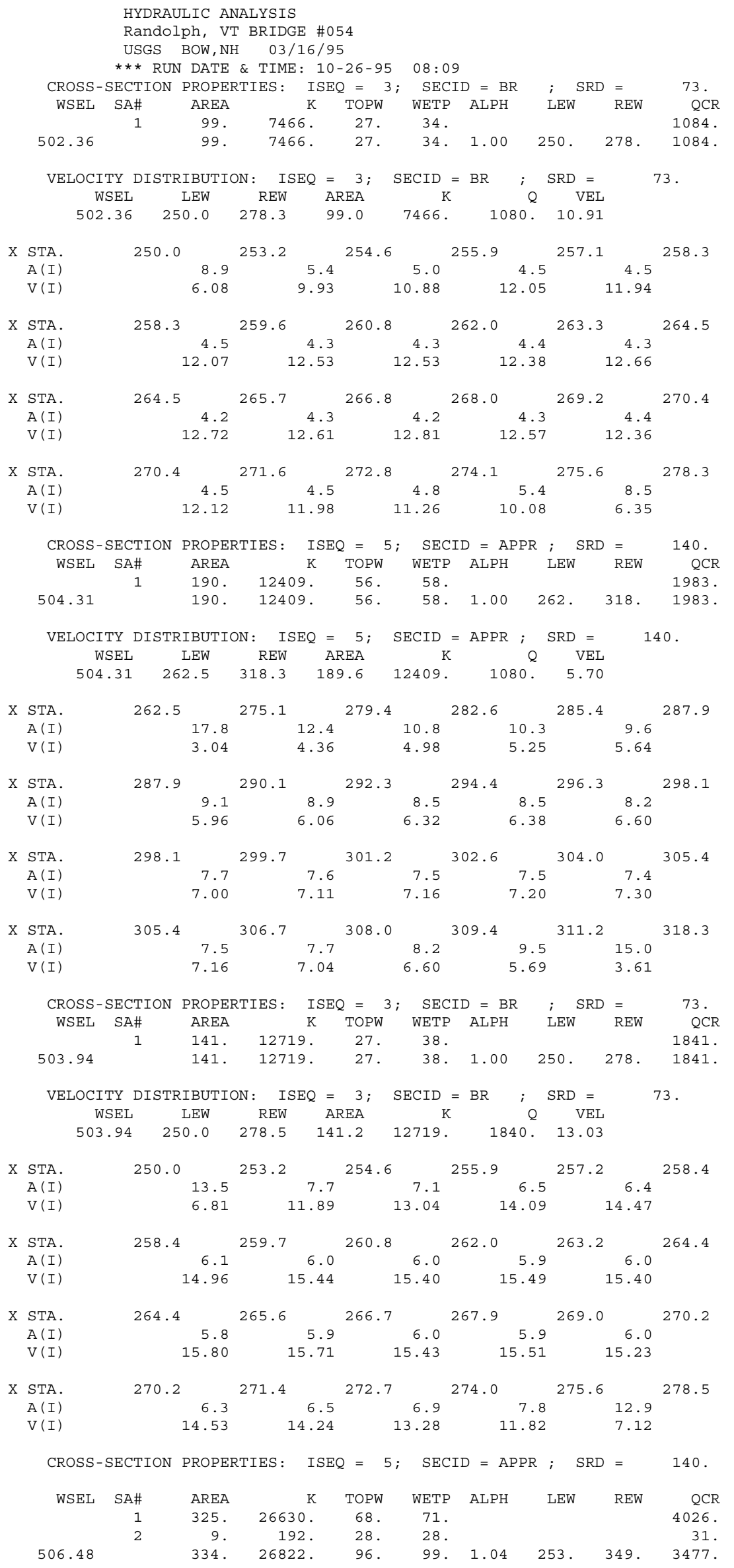


WSPRO OUTPUT FILE (continued)

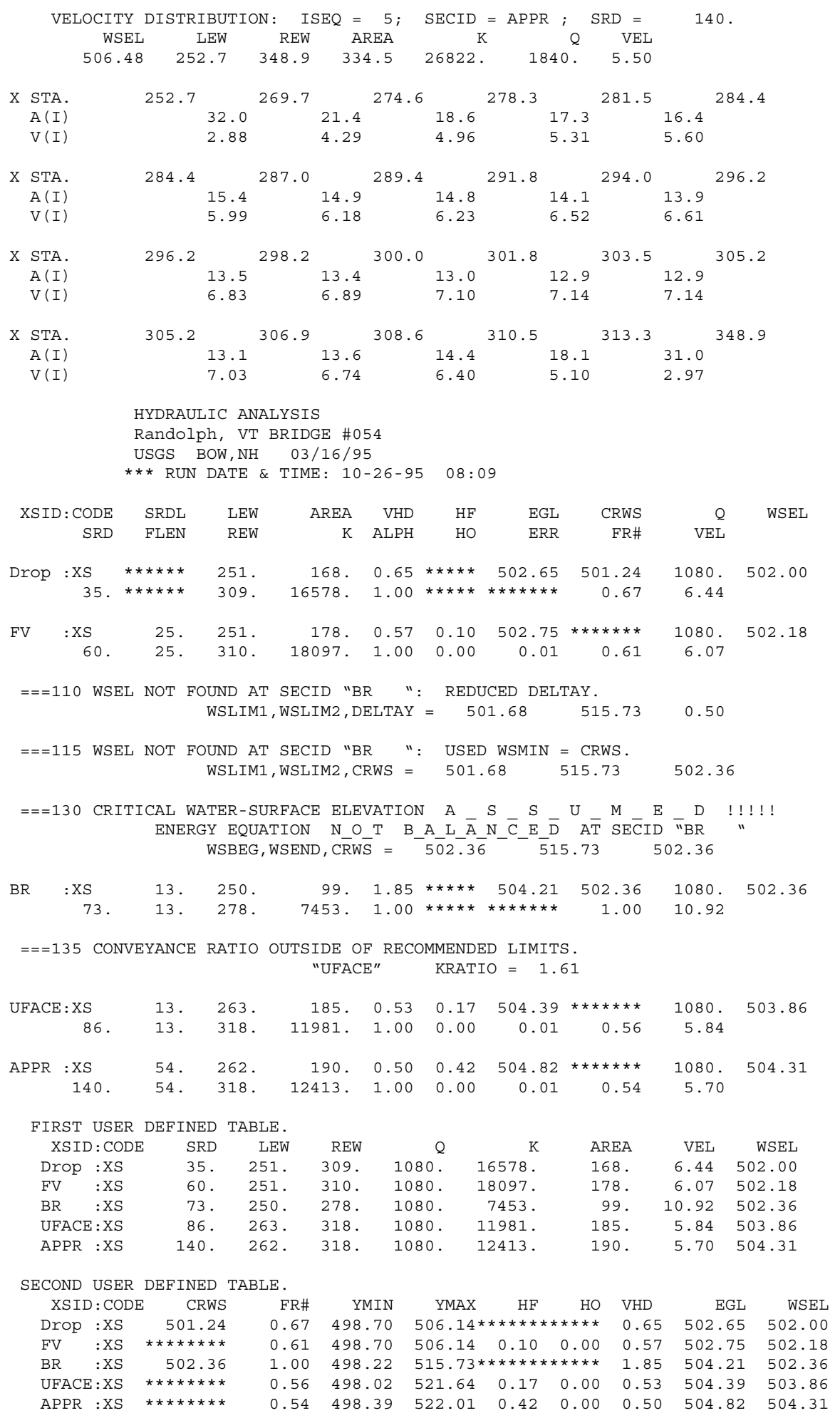




\section{WSPRO OUTPUT FILE (continued)}

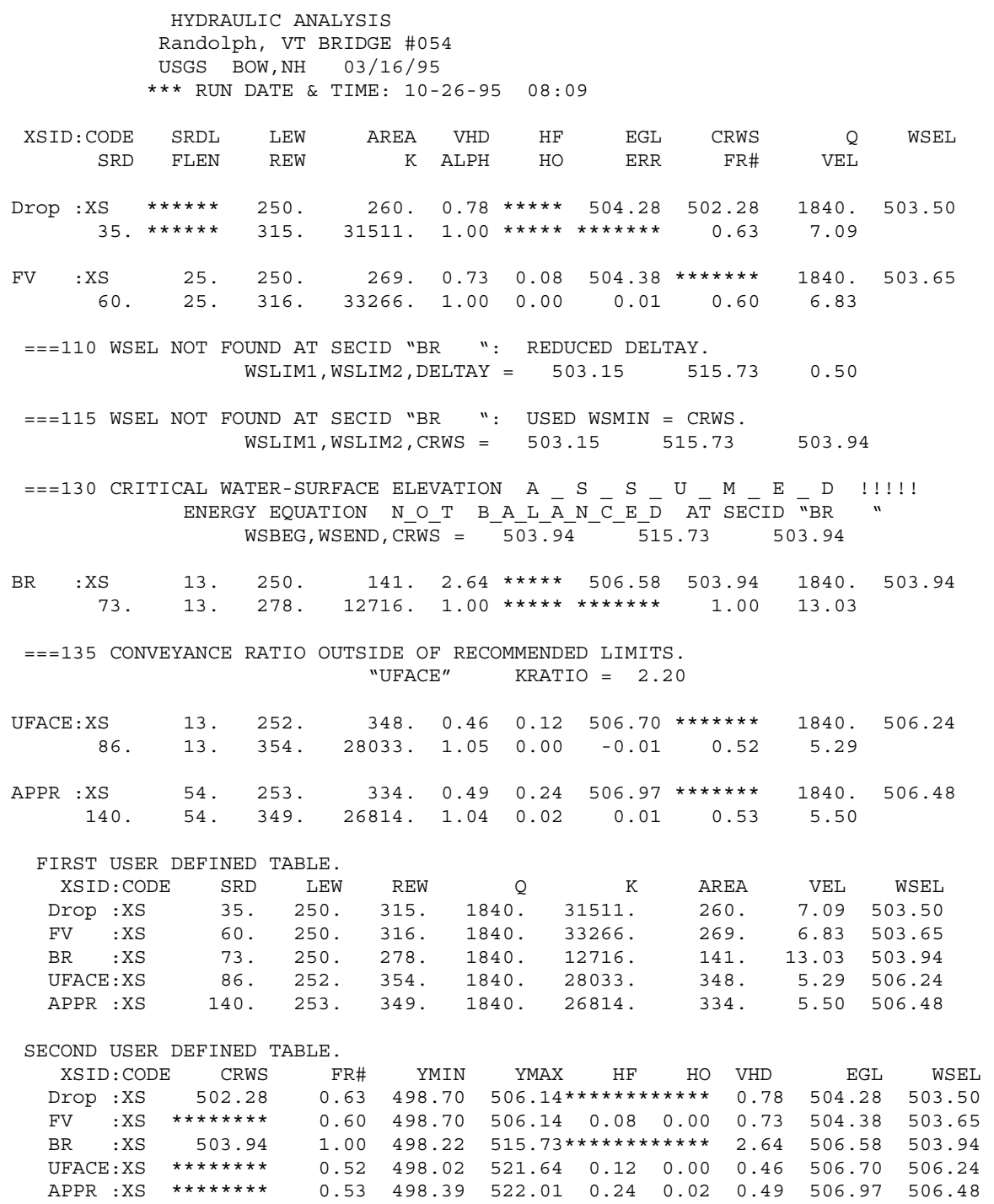




\section{APPENDIX C:}

\section{BED-MATERIAL PARTICAL-SIZE DISTRIBUTION}




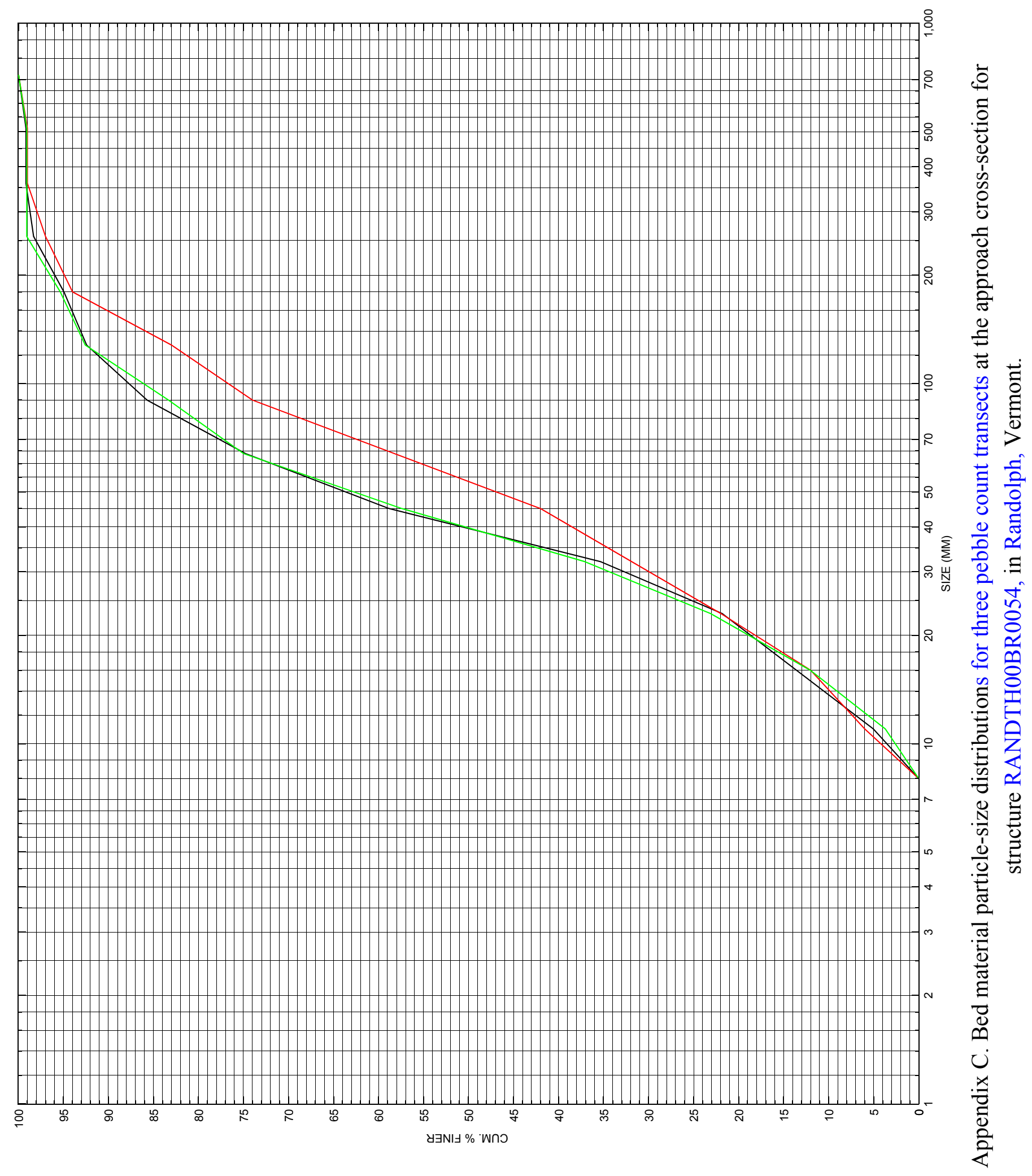




\section{APPENDIX D: \\ HISTORICAL DATA FORM}

